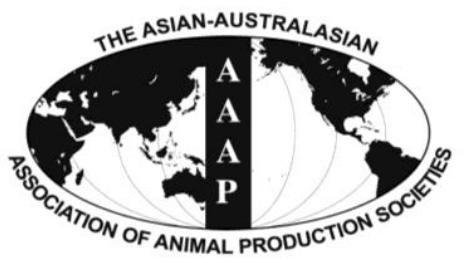

Asian-Aust. J. Anim. Sci.

Vol. 26, No. 2 : 295-302 February 2013

http://dx.doi.org/10.5713/ajas.2012.12432

www.ajas.info

pISSN 101 1-2367 elSSN 1976-5517

\title{
Chemical Composition and Meat Quality Attributes of Indigenous Sheep and Goats from Traditional Production System in Tanzania
}

\author{
Dismas S. Shija*, Louis A. Mtenga, Abiliza E. Kimambo, Germana H. Laswai, Daniel E. Mushi, \\ Dynes M. Mgheni, Angello J. Mwilawa ${ }^{1}$, Eligy J. M. Shirima ${ }^{2}$ and John G. Safari ${ }^{3}$ \\ Department of Animal Science and Production, Sokoine University of Agriculture, \\ P.O. Box 3004, Morogoro, Tanzania
}

\begin{abstract}
The aim of the study was to compare chemical composition and quality attributes of meat between male long fat tailed sheep $(\mathrm{n}=17)$ and Small East African goats $(\mathrm{n}=17)$ existing in Tanzania. Animals of 1.5 to 2 yrs in age and live body weight of $22.59 \pm 0.50 \mathrm{~kg}$ were purchased from livestock auction markets. Animals were fasted for $18 \mathrm{~h}$ and slaughtered according to standard halal procedure. Left carcasses were dissected into muscles, fat and bone and the muscle and fat were mixed together and chemically analysed. Meat quality attributes were measured based on Muscle longissimus thoracis et lumborum excised from right sides of carcasses. Goat carcasses had significant higher $(p=0.0302)$ moisture content $(70.65 \%$ vs $66.96 \%)$ and lower $(p=0.0027)$ ether extract $(2.49 \%$ vs $5.82 \%)$ than sheep but there was no significant species differences in protein and ash content. Sheep had lower $(\mathrm{p}=0.0157)$ ultimate $\mathrm{pH}\left(5.74\right.$ vs 5.88) and higher $(\mathrm{p}=0.0307)$ temperature $\left(3.77^{\circ} \mathrm{C}\right.$ vs $\left.3.15^{\circ} \mathrm{C}\right)$ than goat carcasses. Sheep meat had lower $(\mathrm{p}=$ $0.0021)$ shear force values $(29.83 \mathrm{~N}$ vs $34.07 \mathrm{~N})$ than goat. Within species, at day 9 of ageing, meat tenderness improved $(\mathrm{p}=0.0001)$ by $44.63 \%$ and $34.18 \%$ for sheep and goat. Pooled data showed that at $\mathrm{d} 9$ of ageing, meat tenderness improved $(\mathrm{p}=0.0001)$ by $39.25 \%$ (from $39.54 \mathrm{~N}$ to $24.02 \mathrm{~N}$ ) compared to tenderness of meat which was not aged at day one of slaughter. The present study demonstrated the differences in chemical composition and quality attributes of meat existing between sheep and goats originated from East Africa. (Key Words: Ageing, Chemical Composition, Goat, Meat Quality, Sheep)
\end{abstract}

\section{INTRODUCTION}

Sheep and goats make an indispensable contribution to food, agriculture, and rural development in many parts of the world particularly in Sub-Saharan Africa (Green, 1986; Kitalyi et al., 2005). In Tanzania, the population of sheep and goats is mostly located in smallholder farming areas and their main function is the production of meat. The traditional production system is extensive, with grazing on natural pastures being a common practice (Mushi et al.,

\footnotetext{
* Corresponding Author: Dismas S. Shija. Tel: +255-757144700, Fax: +255-232604562, E-mail: shija78@ gmail.com

${ }^{1}$ National Livestock Research Institute, P.O. Box 202, Mpwapwa, Tanzania.

${ }^{2}$ Ministry of Livestock and Fisheries Development, P. O. Box 9152, Dar es Salaam, Tanzania.

${ }^{3}$ Institute of Rural Development and Planning, P.O. Box 138, Dodoma, Tanzania.

Submitted Aug. 10, 2012; Accepted Sept. 22, 2012; Revised Sept. 28, 2012
}

2009). This system involves slaughtering animals at the age of 2 yrs with live body weight (BW) of approximately 20 $\mathrm{kg}$ (Mushi, 2004). However, there is limited research on meat quality attributes like tenderness and carcass composition from such a production system (Mushi et al., 2007). Tenderness is the primary determinant of eating quality and acceptability of meat (Voges et al., 2007; Destefanis et al., 2008).

In most studies, meat tenderness has been evaluated instrumentally using the Warner-Bratzler shear method, which gives the best correlation with sensory panel scores for tenderness within muscles (Destefanis et al., 2008; Schönfeldt and Strydom, 2011). Perry et al. (2001) reported that a shear force below $4 \mathrm{~kg}(40 \mathrm{~N})$ is what equates to meat with an acceptable level of tenderness in Australian markets. However, extensive review of previous meat tenderness estimates by Hopkins et al. (2006) and Shorthose et al. (1986) concluded that sheep meat with shear force values less than $49 \mathrm{~N}$ is considered and acknowledged as tender. 
Nonetheless, results obtained from such studies measuring shear force have been widely variable depending on experimental conditions like animal management regime, species, muscle temperature, muscle $\mathrm{pH}$ decline, and meat ageing (Schönfeldt and Strydom, 2011). Low pH and high carcass temperature can enhance the disruption of the lysosomal membrane to release cathepsins, which will then have access to myofibril proteins resulting in meat tenderness (O’Halloran et al., 1997; Hopkins and Taylor, 2002). There is a general conception that goat meat is inferior to other species meat in tenderness (Lee et al., 2008). Compared to sheep, goat meat tends to be less tender, with high shear force values and collagen content (McMillin and Brock, 2005; Webb et al., 2005). High pH values $(>6.00)$ for goat muscles compared to the $\mathrm{pH}$ values of muscle from other species, have been found in many studies (Webb et al., 2005).

Carcass composition is another important aspect of meat quality and is normally assessed by amount of physical dissected tissues (muscle, fat and bones) or chemical analysed constituents i.e. protein, fat, water and ash (Moran and Wood, 1986). Several studies have been conducted to compare chemical composition of sheep and goats at the same slaughter weight, age or under similar feeding management (Babiker et al., 1990; Sen et al., 2004; Santos et al., 2008). It has been found that, goat meat is characterised by low intramuscular fat and higher moisture content (Babiker et al., 1990; Mahgoub and Lodge, 1998) at comparable ages and slaughter weight. Although there is a great deal of documentation on chemical composition and meat quality of sheep and goat meat (Lee et al., 2008; Santos et al., 2008), detailed information of these parameters in sheep and goats in the tropics especially from traditional production systems is missing. Such information on inherent meat quality of sheep and goats is required to help consumers make an informed decision in purchasing meat. Thus, the aim of this study was to compare chemical composition and quality attributes of meat from mature male sheep and goats raised under traditional production system.

\section{MATERIALS AND METHODS}

\section{Location}

The study was conducted in Dodoma region, central Tanzania, which is located at $6^{\circ} 10^{\prime} 23^{\prime \prime} \mathrm{S} 35^{\circ} 44^{\prime} 31^{\prime \prime} \mathrm{E}$, and $1,120 \mathrm{~m}$ above sea level. The region features a semi-arid climate with relatively warm temperatures at $16^{\circ} \mathrm{C}$ and $29^{\circ} \mathrm{C}$ on average between low and high records in the year. It has unimodal rainfall pattern with annual precipitation of $570 \mathrm{~mm}$, the bulk of which occurs between December and April.

\section{Animals and management}

Thirty-four animals (17 sheep and 17 goats) were bought from livestock auction markets. The animals were purposely selected to include only animals ranging in live BW from $20 \mathrm{~kg}$ to $25 \mathrm{~kg}$ (the mean of $22.59 \pm 0.50 \mathrm{~kg}$ live BW) and age from 1.5 to 2 yrs. The age of animals was estimated by the pattern of eruption of the incisor teeth, whereby those with the first pair of permanent incisors were sampled (Abegaz and Awgichew, 2009). Each animal was marked using blue paint before being transported by truck to the department of Meat Processing Technology (MPT) of Dodoma Regional Vocational Education Training and Services Centre (DRVETSC) for slaughtering and carcass evaluation. At MPT, all animals were kept in the lairage and fasted for $18 \mathrm{~h}$ with free access to water. Slaughter live BW were taken $16 \mathrm{~h}$ prior to slaughter using mechanical weighing balance (100 kg, Golden Lark, China).

\section{Slaughtering procedure}

The animals were slaughtered according to standard commercial halal procedures and bleeding was effected by severing the carotid arteries and jugular vein in a single cut. The head was removed at the atlanto-occipital joint and fore and hind feet removed at the carpus-metacarpal and tarsusmetatarsal joints, respectively (Bonvillani et al., 2010). After dressing, the carcasses were labelled for subsequent measurements.

\section{Temperature and $\mathrm{pH}$ measurements}

Temperature and $\mathrm{pH}$ measurements were taken on the left side of carcasses at the same point on the Muscle longissimus thoracis et lumborum (LL) between the 5th and 6 th rib.

Initial $\mathrm{pH}\left(\mathrm{pH}_{45}\right)$ and temperature $\left(\mathrm{T}_{45}\right)$ was measured within $45 \mathrm{~min}$ post slaughter. Subsequent readings were taken at 3, 6, 12 and $24 \mathrm{~h}$ post mortem whereby the $\mathrm{pH}$ readings were designated as $\mathrm{pH}_{45}, \mathrm{pH}_{3}, \mathrm{pH}_{6}, \mathrm{pH}_{12}$ and $\mathrm{pH}_{24}$ (ultimate $\mathrm{pH}$ ), respectively. Temperature readings were designated as $\mathrm{T}_{45}, \mathrm{~T}_{3}, \mathrm{~T}_{6}, \mathrm{~T}_{12}$ and $\mathrm{T}_{24}$, respectively. The $\mathrm{pH}$ was taken using penetrating electrode (Mettler Toledo) of a portable pH-metre (Knick-portamess 911, Germany). The probe was calibrated with $\mathrm{pH} 4$ and 7 standard buffer solutions. The temperature was measured by insertion of the thermometer pointer to the muscle. The temperatures were recorded using FUNKUTION Digital stegetermometer (Digital thermometer) meat thermometer. Before and after every reading the electrode and thermometer pointer were thoroughly cleaned with distilled water and cotton towel. Ultimate $\mathrm{pH}(\mathrm{pHu})$ and temperature was taken after complete glycolysis at $24 \mathrm{~h}$ post mortem.

\section{Carcass splitting and dissection for chemical}




\section{composition analysis}

After $24 \mathrm{~h}$ of storage, carcasses were split longitudinally to obtain left and right sides. The left half of each carcass was dissected into muscle, external fat and bone components. The meat (muscle) samples were minced through a $5 \mathrm{~mm}$ plate meat-grinding machine. The minced meat was sampled, vacuum packed and frozen for subsequent chemical analysis. Chemical composition analysis of minced meat samples was performed on wet basis by proximate analysis to determine moisture, ash, crude protein and fat content (AOAC, 2007) using the laboratory at the Department of Animal Science and Production of Sokoine University Agriculture.

\section{Muscle sampling and conditioning for meat tenderness analysis}

Muscle longissimus thoracis et lumborum (LL) was excised from the right half of carcasses, $24 \mathrm{~h}$ post mortem for meat tenderness analysis. The LL was excised from carcass between the 6 th rib and last lumbar vertebrae. The sampled LL was divided into five blocks measuring approximately $6 \mathrm{~cm}$ long. The blocks were assigned to 1,2 , 4, 6 and $9 \mathrm{~d}$ of ageing period and designated as $\mathrm{LL}_{1}, \mathrm{LL}_{2}$, $\mathrm{LL}_{4}, \mathrm{LL}_{6}$ and $\mathrm{LL}_{9}$, respectively. All samples were vacuum packed into plastic bags before storage. Those assigned to day one $\left(\mathrm{LL}_{1}\right)$ ageing were immediately stored in a freezer at $-18^{\circ} \mathrm{C}$ whereas those assigned to $\mathrm{LL}_{2}, \mathrm{LL}_{4}, \mathrm{LL}_{6}$ and $\mathrm{LL}_{9}$ ageing were stored in a chilling room at $4^{\circ} \mathrm{C}$ for the intended duration before being moved into the freezer for subsequent analyses.

\section{Thawing loss, cooking loss and shear force}

When the five blocks of LL samples were removed from the freezer, they were weighed $\left(\mathrm{W}_{1}\right)$ to get weight before thawing and thawed at $4^{\circ} \mathrm{C}$ overnight. Then, samples were weighed again to get weight after thaw $\left(\mathrm{W}_{2}\right)$ and thawing loss was then calculated $(\%)$ as $\left(\left(\mathrm{W}_{1}-\mathrm{W}_{2}\right) / \mathrm{W}_{1}\right) \times 100$. After thawing the pieces of LL muscle, they were packed into the watertight plastic bag and boiled in a thermostatically controlled water bath set at $80^{\circ} \mathrm{C}$ for $1 \mathrm{~h}$. After boiling, the samples were cooled for $2 \mathrm{~h}$ in a cold running water, blotted dry with dry towel and weighed $\left(\mathrm{W}_{3}\right)$ for determination of cooking loss $(\%),\left(\left(\mathrm{W}_{2}-\mathrm{W}_{3}\right) / \mathrm{W}_{2}\right) \times 100$. Three sub-samples cut parallel to the muscle fibres direction with a cross section of $1 \times 1 \mathrm{~cm}$ were removed from each cooked LL sample. Shear force values of sub-samples were determined using a Zwick/Roell (22.5 Germany) equipped with a Warner Bratzler (WB). Each sub-sample obtained from cooked LL sample was sheared twice and the forces obtained were recorded. An average of shear force for three sub-samples sheared twice was calculated and recorded as a maximum shear force value for a particular LL sample.

\section{Statistical analysis}

The data were analysed using the GLM procedures of SAS (2000) to determine the influence of species on carcass temperature, $\mathrm{pH}$ values and chemical composition. Thawing loss, cooking loss and shear force values were tested for effect of between species, and ageing period for $\mathrm{d} 1,2,4,6$ and 9 within species. The difference between the least squares means for sheep and goats were compared by PDIFF.

\section{RESULTS AND DISCUSSION}

\section{Meat chemical composition}

The meat from goat carcasses contained significantly more $(p=0.0302)$ moisture content and lower $(p=0.0027)$ ether extract than sheep whereas protein and ash contents were not significant between the two species (Table 1). These findings are in line with previous studies where goat meat is characterised by low intramuscular fat and higher moisture content (Babiker et al., 1990; Mahgoub and Lodge, 1998). Tshabalala et al. (2003) also observed similar trend when carcass chemical composition of goats and sheep were compared.

Hogg et al. (1992) reported that goat meat contained little fat and therefore relatively higher proportions of protein and minerals. Further in support of the current study, Babiker et al. (1990) reported goat meat have significantly $(p<0.05)$ less intramuscular fat and significantly $(p<0.001)$ more moisture than sheep. On the other hand, Lee et al. (2008) found no significant differences in moisture, protein and fat contents between goats and sheep. There are many factors, which can contribute to lack of agreement on effects of species on chemical composition between authors. These factors, which are often difficult to control between studies, include differences in maturity, breed, production systems, and feeding management of animals used in these studies.

\section{Temperature and $\mathrm{pH}$ changes}

As expected, there was a decrease in $\mathrm{pH}$ and temperature with time in both sheep and goats carcasses

Table 1. Least squares means for chemical composition (\% fresh weight basis) of the left half carcass from sheep $(n=17)$ and goats $(\mathrm{n}=17)$

\begin{tabular}{|c|c|c|c|c|}
\hline \multirow{2}{*}{ Variable } & \multicolumn{2}{|c|}{ Species } & \multirow{2}{*}{ SEM } & \multirow{2}{*}{ p-value } \\
\hline & Sheep & Goat & & \\
\hline Moisture content & $66.96^{\mathrm{b}}$ & $70.65^{\mathrm{a}}$ & 1.18 & 0.0302 \\
\hline Crude protein & 22.49 & 23.45 & 0.99 & 0.4936 \\
\hline Ether extract & $5.82^{\mathrm{a}}$ & $2.49^{\mathrm{b}}$ & 0.76 & 0.0027 \\
\hline Ash content & 3.90 & 4.40 & 0.24 & 0.1362 \\
\hline
\end{tabular}

$\mathrm{a}, \mathrm{b}$ The means with different letters in the same row differ significantly $(\mathrm{p}<0.05)$. 
(Table 2; Figure 1). The difference in $\mathrm{pH}$ readings recorded at $45 \mathrm{~min}$ and $3 \mathrm{~h}$ were not significant between sheep and goats. However, the differences in muscle $\mathrm{pH}$ recorded at 6 $\mathrm{h}, 12 \mathrm{~h}$ and $24 \mathrm{~h}$ were significant between sheep and goats. The $\mathrm{pH}$ readings recorded for sheep declined faster than that of goats and reached below $6.0(\mathrm{p}=0.0011)$ at $6 \mathrm{~h}$ post mortem. Thus, the average $\mathrm{pHu}$ for goat carcasses was higher $(\mathrm{p}=0.0157)$ than sheep at $24 \mathrm{~h}(5.88$ vs 5.74). Previous studies (Atti et al., 2006; Mushi et al., 2009; Ding et al., 2010) have reported similar results to the current observations of higher $\mathrm{pHu}$ for goat meat. However, there are reports elsewhere where goat meat have found with normal pHu of about 5.6, for example, in Liuyang black goat (Zhong et al., 2009), in Moxotó and Canidé goat (Madruga et al., 2008) and in Greek goats (Arsenos et al., 2009). On the other hand, sheep expressed lower $\mathrm{pHu}$ as compared to goat carcasses.

This can be partly related to post mortem glycogen conversion into lactate and $\mathrm{H}^{+}$resulting into a decrease in $\mathrm{pH}$ of meat, and partly to glycogen levels at slaughter, which is inversely related to the $\mathrm{pHu}$ (Vestergaard et al., 2000). Another reason for observed species variation in $\mathrm{pHu}$ in this study is the possible differences in response to preslaughter stress between sheep and goats (Santos et al., 2007). Goats have been reported to be more prone to preslaughter stresses than sheep (Santos et al., 2007; Santos et al., 2008). Depletion of muscular glycogen reserves because of pre-slaughter stress probably had a considerable influence on $\mathrm{pH}$ values in goat carcasses. The average $\mathrm{pHu}$ of 5.74 and 5.88 for sheep and goats carcasses at $24 \mathrm{~h}$ post mortem observed in the present study is $<6.00$ compared to observations reported by other workers (Webb et al., 2005; Safari et al., 2010).

Temperature of goat carcasses declined at faster rate than that of sheep carcasses (Table 2; Figure 2). Carcass temperature measured at $45 \mathrm{~min}, 3 \mathrm{~h}$, and $6 \mathrm{~h}$ post mortem did not differ significantly between the two species, but
Table 2. Least squares means of $\mathrm{pH}$ and temperature $\left({ }^{\circ} \mathrm{C}\right)$ values of sheep $(\mathrm{n}=17)$ and goats $(\mathrm{n}=17)$ carcasses at $45 \min , 3,6,12$ and $24 \mathrm{~h}$ post mortem

\begin{tabular}{lcccc}
\hline \multirow{2}{*}{ Variable } & \multicolumn{2}{c}{ Species } & \multirow{2}{*}{ SEM } & p-value \\
\cline { 2 - 3 } & Sheep & Goat & & \\
\hline pH readings & & & & \\
$\mathrm{pH}_{45}$ & 6.50 & 6.57 & 0.04 & 0.2170 \\
$\mathrm{pH}_{3}$ & 6.13 & 6.24 & 0.05 & 0.1207 \\
$\mathrm{pH}_{6}$ & $5.81^{\mathrm{b}}$ & $6.10^{\mathrm{a}}$ & 0.06 & 0.0011 \\
$\mathrm{pH}_{12}$ & $5.75^{\mathrm{b}}$ & $5.93^{\mathrm{a}}$ & 0.04 & 0.0017 \\
$\mathrm{pH}_{24}$ & $5.74^{\mathrm{b}}$ & $5.88^{\mathrm{a}}$ & 0.04 & 0.0157 \\
Temperature $\left({ }^{\circ} \mathrm{C}\right)$ & & & & \\
$\mathrm{T}_{45}$ & 34.50 & 34.59 & 0.41 & 0.8811 \\
$\mathrm{~T}_{3}$ & 25.35 & 25.21 & 0.19 & 0.5858 \\
$\mathrm{~T}_{6}$ & 23.47 & 23.65 & 0.15 & 0.3995 \\
$\mathrm{~T}_{12}$ & $5.00^{\mathrm{a}}$ & $4.44^{\mathrm{b}}$ & 0.14 & 0.0063 \\
$\mathrm{~T}_{24}$ & $3.77^{\mathrm{a}}$ & $3.15^{\mathrm{b}}$ & 0.20 & 0.0307 \\
\hline
\end{tabular}

${ }_{\mathrm{a}, \mathrm{b}}$ The means with different letters in the same row differ significantly $(\mathrm{p}<0.05) . \mathrm{SEM}=$ Standard error of mean; $\mathrm{T}=$ Temperature at $45 \mathrm{~min}, 3$, 6,12 and $24 \mathrm{~h}$ post mortem.

goat carcasses had lower temperatures than sheep carcasses at $12 \mathrm{~h}$ and $24 \mathrm{~h}$ post mortem readings. The observed differences in temperature decline between goat and sheep carcasses are probably due to the difference in fat coverage and size of goat and sheep carcasses. Leaner and small sized carcasses normally dissipate heat at a rapid rate during the immediate post mortem period whereas large carcasses with high fat cover are associated with a slower temperature decline (Koohmaraie, 1988; Kouakou et al., 2005).

\section{Shear force, thawing and cooking loss}

In this study, sheep meat had higher thawing loss, cooking loss and lower shear force values than goat meat (Table 3). Sheep meat was more tender than goat meat by $12.44 \%(4.24 \mathrm{~N})$, the difference being significant $(\mathrm{p}=$ $0.0021)$. The higher tenderness observed in sheep meat was also in agreement with Sen et al. (2004) who reported

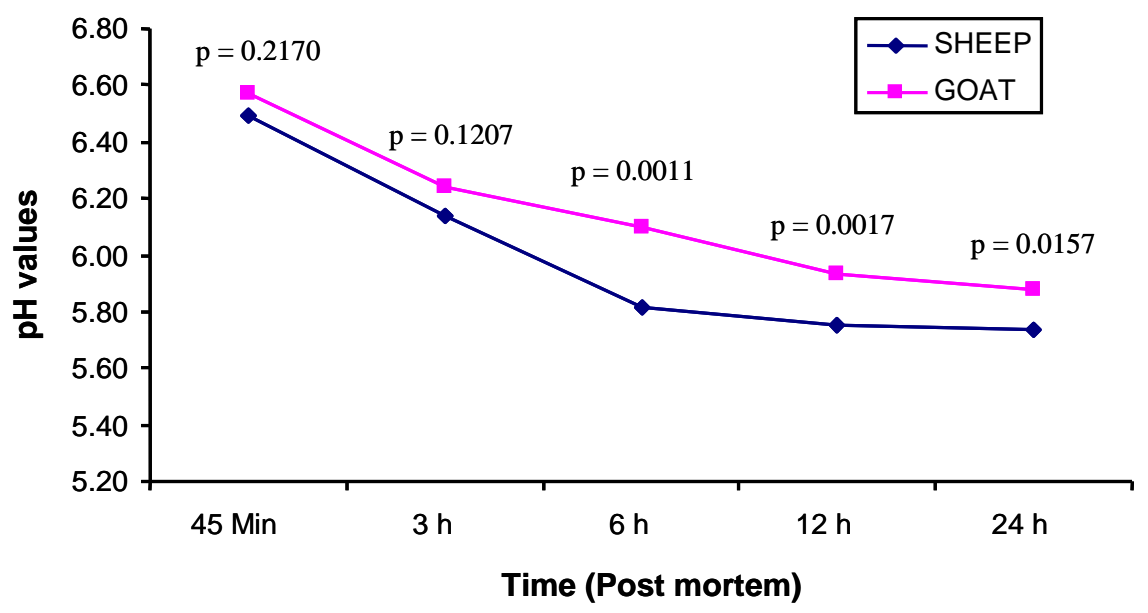

Figure 1. $\mathrm{pH}$ decline post mortem for sheep $(\mathrm{n}=17)$ and goats $(\mathrm{n}=17)$ carcasses. 


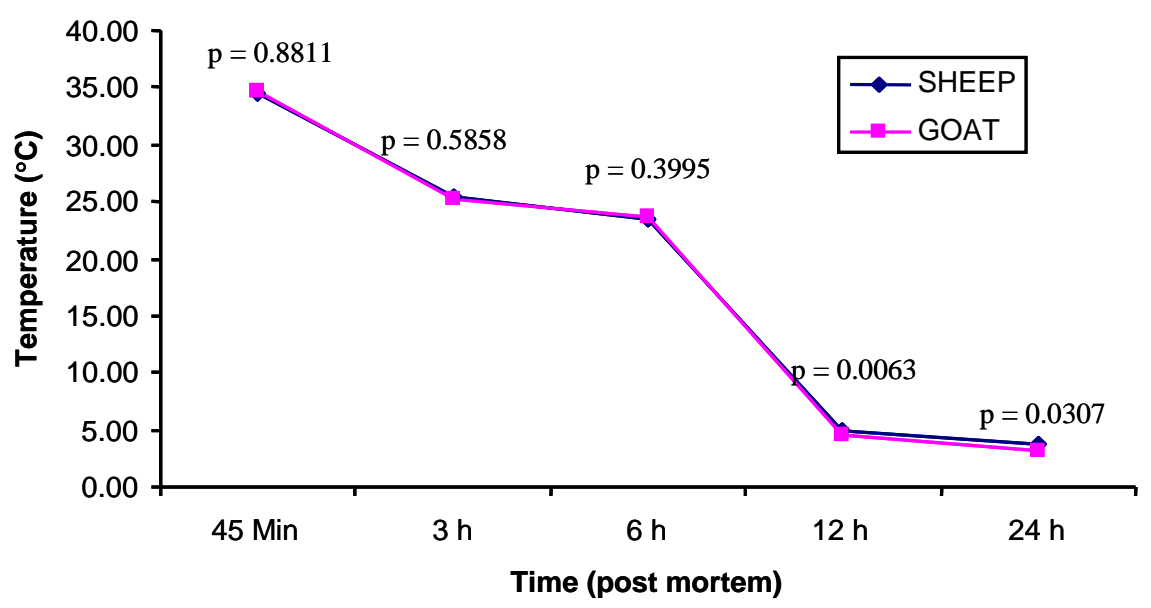

Figure 2. Temperature decline post mortem for sheep $(n=17)$ and goats $(n=17)$ carcasses.

higher tenderness in sheep meat $(37.4 \mathrm{~N})$ compared to yearling goats $(74.2 \mathrm{~N})$. Gaili and Ali (1985) suggested that the tendency for goat meat to be tough was due to fact that goat muscle fibres are thicker and the fibre bundles are larger than those in sheep muscle fibres, a factor which was not analysed in the present study due to limited analytical facilities.

The overall differences in tenderness between sheep and goats may be a reflection of differences in the size of muscle fibre. Because animals used in the present study were still growing (at the age of 1.5 to $2 \mathrm{yrs}$ ), it is expected that the muscle type produced by such animals contained low amount of connective tissues. However, shear force values also depend on other factors such as handling prior to and at slaughter, age, breed, type and $\mathrm{pH}$ of muscle used, and cooking temperature and cooking time as reported by previous studies (Ferguson and Warner, 2008; Behrends et al., 2009). Age of animal, for example, is linked with differences in total collagen content and solubility, which account for part of the variation found in tenderness in animals (Tschirhart-Hoelscher et al., 2006; ArchileContreras et al., 2010). It speculative, as also suggested by Wheeler and Koohmaraie (1991), that myofibrillar component between sheep and goats might have been more important factor influencing shear force in the present study than the characteristics of connective tissue. In this respect, LL from both sheep and goats in the present study had shear

Table 3. Least squares means of sheep $(n=17)$ and goats $(n=17)$ for thawing loss, cooking loss and shear force of Longissimus thoracis et lumborum

\begin{tabular}{lcccc}
\hline \multirow{2}{*}{ Variable } & \multicolumn{2}{c}{ Species } & \multirow{2}{*}{ SEM } & \multirow{2}{*}{-value } \\
\cline { 2 - 3 } & Sheep & Goats & & \\
\hline Thawing loss (\%) & $3.95^{\mathrm{a}}$ & $3.23^{\mathrm{b}}$ & 0.24 & 0.0370 \\
Cooking loss (\%) & 20.31 & 18.79 & 0.58 & 0.0652 \\
Shear force (N) & $29.83^{\mathrm{b}}$ & $34.07^{\mathrm{a}}$ & 0.96 & 0.0021 \\
\hline
\end{tabular}

${ }^{\mathrm{a}, \mathrm{b}}$ The means with different letters in the same row differ significantly $(p<0.05)$. SEM $=$ Standard error of mean. force values below $40 \mathrm{~N}$ (Perry et al., 2001; Hopkins et al., 2006), and therefore may be considered tender.

The present results on cooking loss are comparable with that of Lee et al. (2008) who reported low cooking loss of $16.69 \%$ in lambs of different combinations of breeds and $16.95 \%$ for goat meat from Boer $\times$ Spanish goats. In addition, muscle $\mathrm{pH}$ also has shown to affect cooking loss that an increase in $\mathrm{pH}$ leads to a reduction in cooking loss. Hence, other studies have reported a range of 26.5 to $29.2 \%$ in muscles with $\mathrm{pHu}$ of 5.5 to 5.6 from different breeds of goats (Madruga et al., 2008) or 23.8 to $26.7 \%$ in sheep meat with pHu 5.0 to 5.8 (Kadim et al., 2009). Such differences could be due to several factors including the rate of thawing (Uttaro and Aalhus, 2007) and cooking temperature (Jeremiah and Gibson, 2003). However, Babiker et al. (1990) reported that goat meat has significantly higher water holding capacity and lower cooking losses than sheep meat.

Within species, a trend was a decrease in values of thawing, cooking loss and shear force as ageing period progresses, respectively (Table 4). The present results shows that shear force values were affected by ageing period and wide variation within species was noted $(\mathrm{p}=$ 0.0001). As meat tenderness significantly improved with ageing of muscle sample from sheep, the response of goat meat to ageing was relatively poor. At d 9 of ageing, meat tenderness improved by $44.63 \%$ and $34.18 \%$ for sheep and goat. This observation conforms to the view that goat meat does not readily attain a highly acceptable degree of tenderness even after a lengthy of ageing period (Safari et al., 2010). The observed response of meat to post mortem ageing in goat meat could be due to high activity of calpastatins, which are known to inhibit the action of calpains in mediating meat ageing process (Kouakou et al., 2005).

Ageing process increases tenderization by weakening the structural integrity of the myofibrilar proteins (Han et al., 
Table 4. Least squares means of Longissimus thoracis et lumborum for thawing loss (\%), cooking loss (\%) and shear force (N) within species following the period of ageing for sheep $(n=17)$ and goats $(n=17)$

\begin{tabular}{|c|c|c|c|c|c|c|c|c|}
\hline \multirow{2}{*}{ Variable } & & \multicolumn{5}{|c|}{ Ageing period (d) } & \multirow{2}{*}{ SEM } & \multirow{2}{*}{ p-value } \\
\hline & & 1 & 2 & 4 & 6 & 9 & & \\
\hline \multirow[t]{3}{*}{ Thawing loss (\%) } & Sheep & $8.78^{\mathrm{a}}$ & $4.14^{\mathrm{b}}$ & $3.10^{\mathrm{c}}$ & $2.91^{\mathrm{c}}$ & $0.82^{\mathrm{d}}$ & 0.54 & $<0.0001$ \\
\hline & Goat & $6.37^{\mathrm{b}}$ & $4.49^{\mathrm{b}}$ & $2.54^{\mathrm{c}}$ & $2.04^{c}$ & $0.72^{\mathrm{d}}$ & 0.54 & $<0.0001$ \\
\hline & Mean & $7.57^{\mathrm{a}}$ & $4.31^{\mathrm{b}}$ & $2.82^{\mathrm{c}}$ & $2.47^{\mathrm{c}}$ & $0.77^{\mathrm{d}}$ & 0.38 & $<0.0001$ \\
\hline \multirow[t]{3}{*}{ Cooking loss (\%) } & Sheep & $23.09^{\mathrm{a}}$ & $23.47^{\mathrm{a}}$ & $23.06^{\mathrm{a}}$ & $18.29^{\mathrm{b}}$ & $13.64^{\mathrm{c}}$ & 1.29 & $<0.0001$ \\
\hline & Goat & $23.40^{\mathrm{a}}$ & $21.88^{\mathrm{a}}$ & $20.88^{\mathrm{a}}$ & $16.55^{\mathrm{b}}$ & $11.25^{\mathrm{c}}$ & 1.29 & $<0.0001$ \\
\hline & Mean & $23.24^{\mathrm{a}}$ & $22.67^{\mathrm{a}}$ & $21.97^{\mathrm{a}}$ & $17.42^{\mathrm{b}}$ & $12.45^{\mathrm{c}}$ & 0.38 & $<0.0001$ \\
\hline \multirow[t]{3}{*}{ Shear force $(\mathrm{N})$} & Sheep & $38.38^{\mathrm{ab}}$ & $33.91^{\mathrm{bc}}$ & $29.20^{\mathrm{cd}}$ & $26.42^{\mathrm{de}}$ & $21.25^{\mathrm{e}}$ & 2.15 & $<0.0001$ \\
\hline & Goat & $40.70^{\mathrm{ab}}$ & $36.72^{\text {bcd }}$ & $34.50^{\mathrm{cd}}$ & $31.65^{\mathrm{de}}$ & $26.79^{\mathrm{e}}$ & 2.15 & $<0.0001$ \\
\hline & Mean & $39.54^{\mathrm{a}}$ & $35.31^{\text {ba }}$ & $31.85^{b c}$ & $29.04^{c}$ & $24.02^{\mathrm{d}}$ & 1.52 & $<0.0001$ \\
\hline
\end{tabular}

,b,c,d The means with different letters in the same row differ significantly $(\mathrm{p}<0.05)$. SEM = Standard error of mean.

2009), and the rate of tenderization varies with ageing time. The trend was a decrease in thawing loss, cooking loss and shear force values as ageing progresses from $\mathrm{d} 1$ through $\mathrm{d}$ 9. Mean values for thawing loss, cooking loss and shear force at $\mathrm{d} 9$ were $6.8 \%, 10.79 \%$ and $39.25 \%$ lower ( $\mathrm{p}=$ $0.0001)$ compared to values obtained at day one ageing (Table 4). Thus, the current study indicates that there is progress improvement in meat tenderness with post-mortem ageing. This agrees with the statement that holding meat for an extended period in a chilled state $\left(3^{\circ} \mathrm{C}\right.$ to $\left.4^{\circ} \mathrm{C}\right)$ post slaughter leads to improvement in meat tenderness (Lawrie and Ledward, 2006). As muscle is converted to meat, a number of metabolic and structural changes occur, and these changes affect meat tenderness due to changes in the properties of muscle fibres and connective tissue hence increased rate of tenderization of meat varies with ageing period (Warriss, 2004). Thus, the findings presented from the current study are comparable with those of Abdullah and Qudsieh (2009) who found that ageing meat from Awassi ram lambs for $7 \mathrm{~d}$ reduced the shear force from 28.3 $\mathrm{N}$ in $\mathrm{d} 1$ to $20.7 \mathrm{~N}$ in $\mathrm{d} 7$, a reduction of $26 \%$.

This study shows that cooking loss was affected ( $\mathrm{p}=$ 0.0001 ) by ageing period but not by species of the animal. The highest mean for cooking loss was observed in $\mathrm{d} 1,2$ and 4 and the lowest was in d 9 (Table 4). Cooking loss is affected by many complex factors, which were not studied in this such as heat transfer methods and surface and internal temperature of the meat (Panea et al., 2008). Lawrie (1991) noted that these factors favour de-naturation of the muscle proteins and lowering of water-binding capacity thus forcing of expulsion of fluids from the meat.

\section{CONCLUSION}

The present study demonstrates that there are differences in chemical composition and quality attributes of meat in sheep and goats originating from East Africa under the traditional livestock production system. It will be useful to collect more data from the traditional livestock production system as well as further understanding of meat quality attributes of East African indigenous breeds of sheep and goats for comparison with other studies conducted on modern breeds and production system.

\section{ACKNOWLEDGEMENTS}

The financial support from ENRECA IGMAFU Project 841 funded by DANIDA at the Department of Animal Science and Production of Sokoine University of Agriculture is highly acknowledged. Thanks are also due to the department of Meat Processing Technology of Dodoma Regional Vocational Education Training and Service Centre for permission to use its facilities during the study.

\section{REFERENCES}

Abegaz, S. and K. Awgichew. 2009. Estimation of weight and age of sheep and goats. In: ESGPIP (Ethiopia Sheep and Goat Productivity Improvement Program) Technical Bulletin No.23 (Ed. Alemu Yami, T. A. Gipson and R. C. Merkel).

Abdullah, Y. A. and R. I. Qudsieh. 2009. Effect of slaughter weight and ageing time on the quality of meat from Awassi ram lambs. Meat Sci. 82:309-316.

AOAC. 2007. Official methods of analysis (18th ed.). Association of Official Analytical Chemists. Arlington, VA, USA.

Archile-Contreras, A. C., I. B. Mandell and P. P. Purslow. 2010. Disparity of dietary effects on collagen characteristics and toughness between two beef muscles. Meat Sci. 86:491-497.

Arsenos, G., P. Fortomaris, E. Papadopoulos, S. Sotiraki, C. Stamataris and D. Zygoyiannis. 2009. Growth and meat quality of kids of indigenous Greek goats (Capra prisca) as influenced by dietary protein and gastrointestinal nematode challenge. Meat Sci. 82:317-323.

Atti, N., M. Mahouachi and H. Rouissi. 2006. The effect of spineless cactus (Opuntia ficus-indica f. inermis) supplementation on growth, carcass, meat quality and fatty acid composition of male goat kids. Meat Sci. 73:229-235.

Babiker, S. A., I. A. El Khider and S. A. Shafie. 1990. Chemical 
composition and quality attributes of goat meat and lamb. Meat Sci. 28:273-277.

Behrends, S. M., R. K. Miller, J. Rouquette, R. D. Randel, B. G. Warrington, T. D. A. Forbes, T. H. Welsh, H. Lippke, J. M. Behrends, G. E. Carstens and J. W. Holloway. 2009. Relationship of temperament, growth, carcass characteristics and tenderness in beef steers. Meat Sci. 81:433-438.

Bonvillani, A., F. Peña, G. de Gea, G. Gómez, A. Petryna and J. Perea. 2010. Carcass characteristics of Criollo Cordobés kid goats under an extensive management system: Effects of gender and live weight at slaughter. Meat Sci. 86:651-659.

Destefanis, G., A. Brugipaglia, M. T. Barge and E. Molin. 2008. Relationship between beef consumer tenderness perception and Warner-Bratzler shear force. Meat Sci. 78:153-156.

Ding, W., L. Kou, B. Cao and Y. Wei 2010. Meat quality parameters of descendants by grading hybridization of Boer goat and Guanzhong dairy goat. Meat Sci. 84:323-328.

Ferguson, D. M. and R. D. Warner. 2008. Have we underestimated the impact of pre-slaughter stress on meat quality in ruminants? Meat Sci. 80:12-19.

Gaili, E. S. and A. E. Ali. 1985. Meat from Sudan desert sheep and goats. Part 2. Composition of the muscular and fatty tissues. Meat Sci. 13:229-236.

Green, R. H. 1986. Food production and hunger in sub-saharan Africa: Retrospect and Prospect. Int. J. 41:768-801.

Han, J., J. D. Morton, A. E. D. Bekhit and J. R. Sedcole. 2009. Pre-rigor infusion with kiwifruit juice improves lamb tenderness. Meat Sci. 82:324-330.

Hogg, B. W., G. J. K. Mercer, A. H. Kirton and D. M. Duganzich. 1992. Carcass and meat quality attributes of commercial goats in New Zealand. Small Rumin. Res. 8:243-256.

Hopkins, D. L., R. S. Hegarty, P. J. Walker and D. W. Pethick. 2006. Relationship between animal age, intramuscular fat, cooking loss, $\mathrm{pH}$, shear force and eating quality of aged meat from sheep. Aust. J. Exp. Agric. 46:879-884.

Hopkins, D. L. and R. G. Taylor. 2002. Post-mortem muscle proteolysis and meat tenderisation. In: Muscle development of livestock animals (Ed. M. te Pas, M. Everts and H. Haagsman). pp. 363-389. Cambridge, MA, USA: CAB International.

Jeremiah, L. E. and L. L. Gibson. 2003. Cooking influences on the palatability of roasts from the beef hip. Food Res. 36:1-9.

Kadim, I. T., O. Mahgoub, W. Al-Marzooqi, S. Khalaf, S. S. H. AlSinawi and I. S. Al-Amri. 2009. Effects of transportation during the hot season and low voltage electrical stimulation on histochemical and meat quality characteristics of sheep longissimus muscle. Livest. Sci. 126:154-161.

Kitalyi, A., L. A. Mtenga, J. Morton, A. McLeod, P. Thornton, A. Dorward and M. Saadullah. 2005. Why keep livestock if you are poor? In: Livestock and Wealth Creation: Improving the husbandry of Animals kept by resource-poor people in developing countries (Ed. E. Owen, A. Kitaly, N. Jayasural and T. Smith) Nottingham University Press Manor Farm, Main Street, Thrumpton Nottingham NG11 0AX, United Kingdom, p. 551.

Koohmaraie, M. 1988. The role of endogenous proteases in meat tenderness. Proceedings of the 41 st reciprocal meat conference, pp. 89-100.

Kouakou, B., S. Gelaye, G. Kannan, T. D. Pringle and E. A. Amoah. 2005. Blood metabolites, meat quality and muscle calpain-calpastatin activities in goats treated with low doses of recombinant bovine somatotropin. Small Rumin. Res. 57:203212.

Lawrie, R. A. 1991. Meat Science (5th ed.). Oxford: Pergamon Press (Chapter 10).

Lawrie, R. A. and D. A. Ledward. 2006. Lawrie's meat science. CRC, Seventh English edition, Woodhead Publishing Limited and CRC Press LLC, p. 442.

Lee, J. H., G. Kannan, K. R. Eega, B. Kouakou and W. R. Getz. 2008. Nutritional and quality characteristics of meat from goats and lambs finished under identical dietary regime. Small Rumin. Res. 74:255-259.

Madruga, M. S., T. S. Torres, F. F. Carvalho, R. C. Queiroga, N. Narain, D. Garrutti, N. M. A. Souza, C. W. Mattos and R. G. Costa. 2008. Meat quality of Moxotó and Canindé goats as affected by two levels of feeding. Meat Sci. 80:1019-1023.

Mahgoub, O. and G. A. Lodge. 1998. A comparative study on growth, body composition and carcass tissue distribution in Omani sheep and goats. J. Agric. Sci. 131:329-339.

McMillin, K. W. and A. P. Brock. 2005. Production practices and processing for value-added goat meat. J. Anim. Sci. 83:E57E68.

Moran, J. B. and J. T. Wood. 1986. Comparative performance of 5 genotypes of Indonesian large ruminants. 3. Growth and development of carcass tissues. Aust. J. Agric. Res. 37:435447.

Mushi, D. E. 2004. Studies on marketing of meat goats and carcass composition - a case study of Gairo auction markets. MSc. Dissertation, Sokoine University of Agriculture, Morogoro, Tanzania.

Mushi, D. E., L. A. Mtenga and L. O. Eik. 2007. Some factors affecting the quality of meat from ruminants and their relevance to the Tanzanian meat industry - review. Tanzania J. Agric. Sci. 8:173-192.

Mushi, D. E., J. Safari, L. A. Mtenga, G. C. Kifaro and L. O. Eik. 2009. Effects of concentrate levels on fattening performance, carcass and meat quality attributes of Small East African $\times$ Norwegian crossbred goats fed low quality grass hay. Livest. Sci. doi:10.1016/j.livsci.2009.01.012.

O'Halloran, G. R., D. J. Troy, D. J. Buckley and W. J. Reville. 1997. The role of endogenous proteases in the tenderisation of fast glycolysing muscle. Meat Sci. 47:187-210.

Panea, B., C. Sañudo, J. L. Olleta and D. Civit. 2008. Effect of ageing method, ageing period, cooking method and sample thickness on beef textural characteristics. Spanish J. Agric. Res. 6:25-32.

Perry, D., J. M. Thompson, I. H. Hwang, A. Butchers and A. F. Egan. 2001. Relationship between objective measurements and taste panel assessment of beef quality. Aust. J. Exp. Agric. 41:981-989.

Safari, J. G., D. E. Mushi, L. A. Mtenga, G. C. Kifaro and L. O. Eik. 2010. Growth, carcass yield and meat quality attributes of Red Maasai sheep fed wheat straw-based diets. Trop. Anim. Heal. Prod. 43:89-97. DOI 10.1007/s11250-010-9658-3.

Santos, V. A. C., A. O. Silva, J. V. F. Cardoso, A. J. D. Silvestre, S. R. Silva, C. Martins and J. M. T. Azevedo. 2007. Genotype and sex effects on carcass and meat quality of suckling kids protected by the PGI "Cabrito de Barroso". Meat Sci. 75:725736. 
Santos, V. A. C., S. R. Silva and J. M. T. Azevedo. 2008. Carcass composition and meat quality of equally mature kids and lambs. J. Anim. Sci. 86:1943-1950.

SAS. 2000. Statistical analysis system, user's guide, Version 8.2. SAS Institute, INC Carry. NC. USA.

Schönfeldt, H. C. and P. E. Strydom. 2011. Effect of age and cut on tenderness of South African beef. Meat Sci. 87:206-208.

Sen, A. R., A. Santra and S. A. Karim. 2004. Carcass yield, composition and meat quality attributes of sheep and goat under semiarid conditions. Meat Sci. 66:757-763.

Shorthose, W. R., V. H. Powell and P. V. Harris. 1986. Influence of electrical stimulation, cooking rates and ageing on shear force values of chilled lambs. J. Food Sci. 51:889-892, 928.

Tschirhart-Hoelscher, T. E., B. E. Baird, D. A. King, D. R. McKenna and J. W. Savell. 2006. Physical, chemical, and histological characteristics of 18 lamb muscles. Meat Sci. 73: 48-54.

Tshabalala, P. A., P. E. Strydom, E. C. Webb and H. L. De Kock. 2003. Meat quality of designated South African indigenous goat and sheep breeds. Meat Sci. 65:563-570.

Uttaro, B. and J. L. Aalhus. 2007. Effects of thawing rate on distribution of an injected salt and phosphate brine in beef. Meat Sci. 75:480-486.
Vestergaard, M., N. Oksbjerg and P. Henckel. 2000. Influence of feeding intensity, grazing and finishing feeding on muscle fibre characteristics and meat colour of semitendinosus, longissimus dorsi and supraspinatus muscles of young bulls. Meat Sci. 54:177-185.

Voges, K. L., C. L. Mason, J. C. Brooks, R. J. Delmore, D. B. Griffin and D. S. Hale. 2007. National beef tenderness survey 2006: Assessment of Warner-Bratzler shear and sensory panel ratings for beef from US retail and foodservice establishments. Meat Sci. 77:357-364.

Warriss, P. D. 2004. Meat Science: An Introductory Text. CABI Publishers, New York, USA. p. 310.

Webb, E. C., N. H. Casey and L. Simela. 2005. Goat meat quality. Small Rumin. Res. 60:153-166.

Wheeler, T. L. and M. Koohmaraie. 1991. A modified procedure for simultaneous extraction and subsequent assay of calciumdependent and lysosomal protease systems from a skeletal muscle biopsy. J. Anim. Sci. 69:1559-1565.

Zhong, R. Z., C. Y. Tan, X. F. Han, S. X. Tang, Z. L. Tan and B. Zeng 2009. Effect of dietary tea catechins supplementation in goats on the quality of meat kept under refrigeration. Small Rumin. Res. 87:122-125. 